\title{
Mucocutaneous findings in pediatric patients with bone marrow transplantation
}

\author{
Kemik iliği transplantasyonu yapılan pediyatrik olgularda mukokutanöz bulgular
}

Serap Aksoylar, Can Ceylan, Aslı Günaydın, İlgen Ertam, Mehmet Kantar*, Arzu Tuna, Nazan Çetingül', Savaș Kansoy*

Ege University Faculty of Medicine, Department of Dermatology and Venereology, ${ }^{*}$ Department of Oncology,

Division of Pediatric Oncology, İmir, Turkey

\begin{abstract}
Background and Design: Bone marrow transplantation (BMT) is performed for many malign and non-malign diseases in pediatric patients. Cutaneous signs in transplant patients are usually encountered in the presence of underlying primary diseases or due to the intense conditioning regimens that include chemotherapy and radiotherapy protocols. In this study, it is aimed to define mucocutaneous changes in pediatric patients with BMT.

Materials and Methods: A total of 44 patients, in whom BMT was planned between 2010 and 2011, were included in the study. Dermatological examinations were performed at the beginning of the study and were repeated once a week in the first month, once a month in the following 5 months; and once in every 3 months in the last 1.5 years of follow-up.

Results: Forty-one patients were completed the study. The mean age of 41 patients was 9.24 years (range: 1-17 years). Of the subjects, $26(64 \%)$ were male and $15(36 \%)$ were female. Dermatological signs, in order of frequency, were mucositis $(75.6 \%)$, xeroderma $(70.7 \%)$, alopecia $(46.3 \%)$, nail disorders $(24.3 \%)$, inflammatory skin diseases $(24.2 \%)$, aphthous stomatitis $(22 \%)$, cutaneous hyperpigmentation (22\%), graft versus host diseases (17.1\%), infectious diseases (15.5\%), and maculopapular rash (4.8\%).

Conclusion: Dermatological diseases can be frequently observed in BMT patients. Close monitoring of dermatological signs is important to minimize the complications of the treatment in this patient group.

Keywords: Child, skin, bone marrow transplantation

Öz

Amaç: Kemik iliği transplantasyonu (KiT), pediyatrik hastalarda birçok malign ve malign olmayan hastalıkta kullanılmaktadır. Transplantasyon yapılan hastalarda gözlenen deri belirtileri, genellikle altta yatan primer hastalığa ya da uygulanan yoğun kemoterapi ve radyoterapi protokollerine bağlı olarak ortaya çıkmaktadır. Bu çalışmada, KiT yapılan pediyatrik olgularda mukokutanöz lezyonların tanımlanması amaçlanmışır. Gereç ve Yöntem: Çalışmaya 2010-2011 yılları arasında KiT yapılması planlanan toplam 44 hasta dahil edilmiştir. Olguların ilk dermatolojik muayeneleri yapıldıktan sonra ilk ay içerisinde her hafta, takip eden 5 aylık süreçte ayda bir ve son 1,5 yılda ise her 3 ayda bir dermatolojik muayeneleri tekrarlanmıştır.

Bulgular: Kırk bir olgu çalışmayı tamamladı. Toplam 41 olgunun yaş ortalaması 9,24 (minimum=1 yaş, maksimum=17 yaş); hastaların 26'sı (\%64) erkek, 15'i (\%36) kadındır. Görülme sıklığı oranlarına göre dermatolojik belirtiler mukozit (\%75,6), kseroderma (\%70,7), alopesi $(\% 46,3)$, aftöz stomatit (\%22), kutanöz hiperpigmentasyon (\%22), tırnak bozuklukları $(\% 24,3)$, enflamatuvar deri hastalıkları $(\% 24,2)$, enfeksiyöz hastalıklar $(\% 15,5)$, graft versus host hastalığı $(\% 17,1)$ ve makülopapüler döküntü $(\% 4,8)$ şeklinde sıralanmıştır. Sonuç: Кіт hastalarında dermatolojik hastalıklar sıklıkla görülebilmektedir. Dermatolojik belirtilerin yakın takibi bu hasta grubunda tedavinin komplikasyonlarını azaltmada önemlidir.
\end{abstract}

Anahtar Kelimeler: Çocuk, deri, kemik iliği transplantasyonu

Address for Correspondence/Yazışma Adresi: Ilgen Ertam MD, Ege University Faculty of Medicine, Department of Dermatology and Venereology, İmir, Turkey Phone: +90 5327154504 E-mail: ilgenertam@gmail.com Received/Geliş Tarihi: 14.01.2015 Accepted/Kabul Tarihi: 07.03.2016

CCopyright 2017 by Turkish Society of Dermatology and Venereology

Turkderm-Turkish Archives of Dermatology and Venereology published by Galenos Yayınevi. 


\section{Introduction}

Bone marrow transplantation (BMT) is a method used in most patients with hematological diseases. Skin symptoms observed in patient who had undergone transplantation are due to underlying diseases or side effects of multiple chemotherapy and radiotherapy treatment. As chemotherapeutics affect cells with high mitotic index, skin, nails and hair may be negatively affected during treatment ${ }^{1-3}$. Additionally, lymphoproliferative diseases may be observed further in these patients ${ }^{4}$. Even though there are some reports of mucocutaneous manifestations in paediatric population receiving BMT, to our knowledge, there are no comprehensive researches published in the literature. The aim of this study was to describe mucocutaneous lesions that occur in paediatric patients receiving BMT.

\section{Materials and Methods}

The study was performed in collaboration with Ege University Faculty of Medicine, Department of Dermatology and Pediatric Bone Marrow Transplantation Unit. It was approved by the Ethics Committee of Ege University (10-11.1/54).

A total 44 patients in whom BMT was planned between 2010 and 2011 years were included in the study. Dermatological examinations were applied once before the treatment and every week of the next one month, once per month over next 5 months and every 3 months over next one and a half years. Patients with cutaneous manifestations were photographed. Skin biopsy was performed in some patients. Informed consent was obtained from the parents of the patients.

In all patients, previous diagnosis, age, sex, stem cell infusion date, transplantation type (allogeneic/autologous), donor type (relative/nonrelative), stem cell source, treatment, and observed mucocutaneous signs/symptoms were noted. Applied treatments were grouped as: chemotherapeutics, antibiotics, antifungals, and antivirals. Observed mucocutaneous signs were classified as infectious dermatosis (mucocutaneous candidiasis, paronychia, tinea versicolor), inflammatory dermatoses (asteatotic eczema, contact dermatitis, seborrhoeic dermatitis), xeroderma, maculopapular eruptions, graft-versus-host disease (GVHD), nail disturbances, alopecia, mucositis, oral aphthous lesions, and skin hyperpigmentation. Three patients were excluded from study: two patients died in post transplantation period and one patient refused to participate in the study after signed the consent form. Therefore, 41 patients were evaluated for mucocutaneous symptoms. The Statistical Package for the Social Sciences and chisquare and Fisher's exact tests were used in statistical analysis.

\section{Results}

Forty-one patients [26 male (64\%), 15 female (36\%)] with a median age of 9.24 years (range: 1-17 years) were included the study. In dermatological examination prior to BMT, no remarkable symptoms were noticed.

Disease and transplantation characteristics of patients are summarized in Table 1, 2.

Primary diagnosis of the patients were classified as hematological malignancies, solid tumors, thalassemia major, bone marrow insufficiency, congenital immune deficiencies and others (familial hemophagocytic lymphohistiocytosis). Hematologic malignancies were acute myeloblastic leukemia, acute lymphoblastic leukemia,
Hodgkin's lymphoma and myelodysplastic syndromes. Solid tumors were neuroblastoma, rhabdomyosarcoma, primitive neuroectodermal tumor, Ewing sarcoma, and congenital immune deficiency syndromes were Wiskott-Aldrich syndrome, x-linked chronic granulomatous disease, major histocompatibility complex (MHC) class 2 deficiency, and interferon-gamma total receptor deficiency.

Allogeneic BMT was performed in 32 (78\%) patients and autologous BMT in nine (22\%) patients. For high-dose chemotherapy, carboplatin/ etoposide/melphalan or busulfan/melphalan were used in solid tumor cases. In all non-relative BMT patients, anti-thymocyte globulin was added to existing therapy. All patients received antibiotic (ciprofloxacin), antiviral (acyclovir) and antifungal (fluconazole) treatment for infection prophylaxis.

Cyclosporine+methotrexate is the most commonly used chemotherapy combination in GVHD prophylaxis. In early post-transplantation period, 40 patients received antibiotic therapy (piperacillin/tazobactam, amikacin, meropenem, teicoplanin) due to febrile neutropenia. Antiemetics, antimicrobial solutions, analgesic drugs and solutions for oral hygiene were used during follow-up. Each patient had shower every day and applied mouthwash with sodium bicarbonate or saline and glutamine 4-6 times a day.

Dermatologic side effects were mucositis (75.6\%), xeroderma (70.7\%), alopecia (46.3\%), aphtous stomatitis (22\%), cutaneous hyperpigmentation (22\%), nail abnormalities (24.3\%), inflammatory skin disease (24.2\%), GVHD (17.1\%), infectious diseases (15.5\%), and maculopapular eruption (4.7\%) (Table 3).

The most frequent inflammatory dermatoses found in our study were seborrhoeic dermatitis (12.1\%), asteatotic eczema (9.7\%) and contact

Table 1. Baseline characteristics of 41 paediatric patients who underwent bone marrow transplantation

\begin{tabular}{|c|c|}
\hline \multicolumn{2}{|l|}{ Characteristics } \\
\hline Age (mean) & $9.2(1-17.5)$ \\
\hline \multicolumn{2}{|l|}{ Sex } \\
\hline Female & 26 \\
\hline Male & 15 \\
\hline \multicolumn{2}{|l|}{ Diagnosis } \\
\hline Hematologic malignities & 18 \\
\hline Solid tumours & 7 \\
\hline Thalassemia major & 7 \\
\hline Bone marrow insufficiency & 5 \\
\hline Congenital immundeficiencies & 4 \\
\hline Others (familial he mophagisitic lymphohistiocytosis) & 1 \\
\hline
\end{tabular}

Table 2. Bone marrow transplantation source

\begin{tabular}{|l|l|}
\hline Transplantation type & 32 \\
\hline Allogenic & 9 \\
\hline Autologous & 23 \\
\hline Donor* & \multicolumn{2}{l|}{} \\
\hline Brother-sister/relative & 8 \\
\hline Matched/not relative & 1 \\
\hline Mismatched/notrelative & \\
\hline *Only allogenic tranplantations ( $n=32)$ &
\end{tabular}


dermatitis (2.4\%); infectious dermatosis were tinea versicolor (8.3\%), mucocutaneous candidiasis (4.8\%) and paronychia (2.4\%).

Six patients (14.6\%) developed acute GVHD, and cutaneuos involvement was observed in all patients. In two cases of acute GVHD, diarrhea and elevated liver enzyme levels were observed; the rest of the patients did not show any signs of gastrointestinal (GIS) involvement. Palmoplantar involvement was documented in all acute and chronic GVHD cases. The cutaneous sign of acute GVHD was erythematous maculopapular rash (Figure 1). Scleroderma-like chronic GVHD was observed in one patient 6 months after BMT. In all cases, GVHD diagnosis was verified by skin biopsies.

No statistically significant difference was found in skin findings between patients who underwent allogeneic BMT and autologous BMT ( $p>0.05$ ). In addition, there was no significant difference in mucocutaneous symptoms between patients who received bone marrow from HLA (human leukocyte antigen)-matched and HLA-mismatched donors. Alopecia was observed more frequently in patients who received bone marrow than in those who received blood-borne stem cells. This difference was statistically significant $(p=0.046)$.

\section{Discussion}

BMT is performed for many indications in pediatric patients nowadays. The incidence of secondary toxic and immunologic reactions has been increased due to the increased number of BMT patients and the intensive chemotherapy regimens applied before $\mathrm{BMT}^{5,6}$

In this study, cutaneous findings in BMT patients were observed in order of mucositis, xeroderma, alopecia and nail disorders.

Mucositis and alopecia were observed more frequently during the $1-3^{\text {th }}$ months of the follow-up, hyperpigmentation, nail disorders and xeroderma were observed after 6 months. There was no statistically significant difference in cutaneous findings between patients who underwent allogeneic BMT and autologous BMT.

Mucositis was the most common finding (75.6\%) in our study. Mucositis is a common finding in patients receiving cancer treatment. Symptoms range from mild pain and erythema to widespread painful ulcerations ${ }^{7}$.

Table 3. Skin findings and their frequencies

\begin{tabular}{|l|l|l|}
\hline Skin findings & No (n) & Frequency (\%) \\
\hline Mucositis & 31 & 75.6 \\
\hline Xerodermia & 29 & 70.7 \\
\hline Alopecia & 19 & 46.3 \\
\hline Nail findings & 10 & 24.3 \\
\hline Aphtous stomatitis & 9 & 22 \\
\hline Hyperpigmentation & 9 & 22 \\
\hline GVHD* & 7 & 17.1 \\
\hline Sebhorreic dermatitis & 5 & 12.1 \\
\hline Asteatotic eczema & 4 & 9.7 \\
\hline Tinea versicolor & 3 & 8.3 \\
\hline Mucocutaneous candidiasis & 2 & 4.8 \\
\hline Maculopapular rash & 2 & 4.8 \\
\hline Paronychia & 1 & 2.4 \\
\hline Contact dermatitis & 1 & 2.4 \\
\hline *GVHD: Graft versus host disease & & \\
\hline
\end{tabular}

Mild erythema is the most frequently reported finding in the literature ${ }^{8}$. Oral care is important in oncology patients. In this finding, in which various oral mucosal care protocols are implemented, misoprostol mouthwash, a synthetic prostaglandin E1 analgesic, was found to be

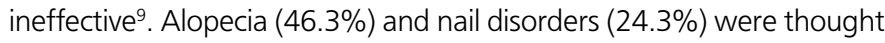
to be associated with negative effects of chemotherapeutic agents on skin appendages with high mitotic activity. Anagen effluvium is often observed within 2-4 weeks following the onset of chemotherapy. In our study, anagen effluvium was observed within one month after starting chemotherapy. Negative effects on the hair follicle are observed earlier in eyebrows, eyelashes, axillary and pubic hair due to the faster cell renewal at the terminal hair follicles. Bleomycin, cisplatin, doxorubicin, melphalan and vincristine are more commonly reported to cause onychodystrophy. Nail disorders observed during chemotherapy are dose-dependent and reversible. Although the mechanism of action is unclear, it is thought that direct toxic or antiangiogenic effects of chemotherapeutic agents are responsible ${ }^{6}$. In addition, immobilization, hypoxia and multiple drug use may be the main reasons for the development of nail dystrophy in patients who have been followed up for long periods in intensive care units after $\mathrm{BMT}^{10}$. Nail changes observed in our study were longitudinal and horizontal ridges, thinning/ brittle splitting nails, and onycholysis.

In the literature, melanonychia associated with the use of hydroxyurea has been reported ${ }^{11}$, but none of the patients using this agent was observed to have melanonychia in our study.

Manzoni et al'. reported that alopecia (73\%), drug-related hyperpigmentation (56\%), petechia and purpura (44\%), mucositis (42\%) and xeroderma (34\%) were observed in their study of 11 pediatric BMT patients. In our study, alopecia was found in $46.3 \%$, hyperpigmentation in $22 \%$, mucositis in $75.6 \%$, and xeroderma in $70.7 \%$ of patients. Factors such as small number of cases in the study of Manzoni et al ${ }^{1}$. and differences in chemotherapy protocols may explain the differences between the results. The higher incidence of mucositis and xeroderma in our cases may also be related to the insufficient care of the patients.

In the literature, the incidence of acute GVHD was reported to be $13 \%$ in patients under 10 years of age and $30 \%$ of patients aged $10-19$ years ${ }^{1}$. The rate of development of GVHD was $17.1 \%$, of which 6 cases were acute and 1 was chronic in our study. GVHD was observed in $16.1 \%$ of patients under 10 years of age, and in $20 \%$ of those older than 10

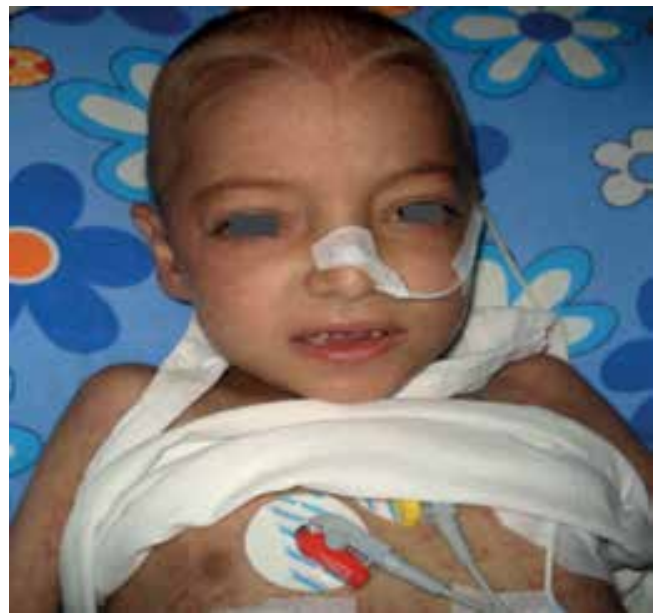

Figure 1. Erythematous maculopapular eruption in an acute graft versus host disease patient 
years. GVHD is a common reaction in BMT patients which may lead to skin and systemic involvement and even may be life-threatening. Skin is the most commonly and initially affected organ. Byun et $\mathrm{al}^{12}$. reported that palmoplantar region and facial involvements were more frequently observed in in adult patients with acute GVHD $(n=22)$ compared to those with drug hypersensitivity reaction $(n=17)$. They also reported that acute GVHD cases are usually asymptomatic and that pruritus is a common symptom in patients with drug hypersensitivity. symptoms, such as diarrhea, abdominal pain, loss of appetite, nausea and vomiting, are frequently seen extracutaneous findings in cases with acute GVHD. The authors have reported that maculopapular eruption persisted more than 2-3 days and diarrhea and hyperbilirubinemia supported the diagnosis of acute GVHD. In our study, 2 of 6 acute GVHD cases had diarrhea and elevated liver function test, while there were no GIS pathologies in other cases. Palmoplantar involvement was observed in all patients with acute and chronic GVHD. Chronic GVHD may develop de novo or may begin as acute GVHD and gradually progress to chronic $\mathrm{GVHD}^{13}$. One of our cases developed scleroderma-like chronic GVHD at 6 months after BMT. Cutaneous hyperpigmentation observed in $22 \%$ of cases is a common side effect of chemotherapeutic agents. Hyperpigmentation may be localized to the skin or it may also lead to mucocutaneous membrane or nail involvement. In our study, the chemotherapeutic agents that frequently caused cutaneous hyperpigmentation were busulfan, cyclophosphamide, hydroxyurea, and methotrexate. Hyperpigmentation has been suggested to be due to secondary toxic effect of chemotherapeutics on melanocytes ${ }^{14}$. Localized hyperpigmentation at the site of administration with generalized hyperpigmentation has also been reported ${ }^{2}$. In our cases, local side effects were not observed in this way.

In the literature, disseminated viral eruptions, especially herpes simplex and varicella-zoster virus infections, have been reported in patients with $\mathrm{BMT}^{15}$. In our study, no viral infection was observed, presumably due to antiviral prophylaxis initiated at an early phase ${ }^{3,16}$.

In our study, maculopapular rashes were detected in two patients $(4.8 \%)$, one of which was due to cefazolin and the other was due to piperacillin-tazobactam. Drug eruption was confirmed by histopathological examination and regressed after the suspected agent was stopped. Intensive chemotherapy protocols with both transplantation and antifungal, antibiotic and antiviral agents may cause many cutaneous side effects in cases of pediatric BMT. Good and effective mucosal protection, close patient follow-up, and prophylaxis given in sufficient doses and on time may minimize the potential complications.

\section{Study Limitations}

This is the first research investigating the skin findings in pediatric cases of BMT in our country, however, there are some limitations such as small sample size, difference between the number of transplantation groups (allogeneic, autologous), small number of patients in whom some drugs were used.

\section{Conclusion}

Identification and classification of mucocutaneous side effects in BMT pediatric patients with larger series of studies will help management of skin findings in these cases.

\section{Ethics}

Ethics Committee Approval: The study were approved by the Ege University Faculty of Medicine of Local Ethics Committee (Protocol number: 10-11.1/54-2011), Informed Consent: Consent form was filled out by all participants.

Peer-review: Externally peer-reviewed.

\section{Authorship Contributions}

Surgical and Medical Practices: Aslı Günaydın, Arzu Tuna, Concept: Can Ceylan, Mehmet Kantar, Design: Illgen Ertam, Data Collection or Processing: Aslı Günaydın, Analysis or Interpretation: Serap Aksoylar, illgen Ertam, Can Ceylan, Nazal Çetingül, Savaş Kansoy, Literature Search: Arzu Tuna, Aslı Günaydın, Writing: Illgen Ertam, Can Ceylan, Serap Aksoylar.

Conflict of Interest: No conflict of interest was declared by the authors. Financial Disclosure: The authors declared that this study received no financial support.

\section{References}

1. Manzoni APDS, Kruse RL, Troian C, et al: Skin changes in pediatric transplant patients. Pediatr Transplant 2006:10:210-4.

2. Kamil N, Kamil S, Ahmed SP, et al: Toxic effects of multiple anticancer drugs on skin. Pak J Pharm Sci 2010;23:7-14

3. Cardoza-Torres MA, Liy-Wong C, Welsh O, et al: Skin manifestations associated with chemotherapy in children with hematologic malignancies. Pediatr Dermatol 2012;29:264-9.

4. Seçkin D: Cutaneous lymphoproliferative disorders in organ transplant recipients: update 2014. G Ital Dermatol Venereol 2014;149:401-8.

5. Otmani $N$, Alami $R$, Hessissen $L$, et al: Determinants of severe oral mucositis in pediatric cancer patients: a prospective study. Int J Pediatr Dent 2011:21:210-6.

6. Huang $\mathrm{V}$, Anadkat M: Dermatologic manifestations of cytotoxic therapy Dermatol Ther 2011:24:401-10.

7. Urbain P, Raynor A, Bertz H, et al: Role of antioxidants in buccal mucosa cells and plasma on the incidence and severity of oral mucositis after allogeneic haematopoietic cell transplantation. Support Care Cancer 2012:20:1831-8.

8. Eduardo F de P, Bezinelli LM, de Carvalho DL, et al: Oral mucositis in pediatric patients undergoing hematopoietic stem cell transplantation: Clinical outcomes in a context of specialized oral care using low-level laser therapy. Pediatr Transplant 2015;19:316-25.

9. Lalla RV, Gordon GB, Schubert M, et al: A randomized, double-blind, placebo-controlled trial of misoprostol for oral mucositis secondary to highdose chemotherapy. Support Care Cancer 2012;20:1797-804.

10. Guhl G, Torrelo A, Hernandez A, Zambrano A: Beau's lines and multiple periungual pyogenic granulomas after long stay in an intensive care unit. Pediatr Dermatol 2008;25:278-9.

11. O'branski EE, Ware RE, Prose NS, Kinney TR: Skin and nail changes in children with sickle cell anemia receiving hydroxyurea therapy. J Am Acad Dermatol 2001;44:859-61

12. Byun HJ, Yang JI, Kim BK, Cho KH: Clinical differentiation of acute cutaneous graft versus host disease from drug hypersensitivity reactions. J Am Acad Dermatol 2011;65:726-32

13. Inalöz S: Liken planus ve likenoid erüpsiyonlar. Dermatoloji. Ed. Tüzün $Y_{\text {, }}$ Gürer MA, Serdaroğlu S, Oğuz O, Aksungur VL: 3. baskı. İstanbul, Nobel Tıp Kitabevleri, 2008;794-5

14. Alley E, Green R, Schuchter L: Cutaneous toxicities of cancer therapy. Curr Opin Oncol 2002;14:212-6.

15. Rau R, Fitzhugh CD, Baird K, et al: Triad of severe abdominal pain, inappropriate antidiuretic hormone secretion, and disseminated varicella zoster virus infection preceding cutaneous manifestations after hematopoietic stem cell transplantatiton. Pediatr Infect Dis J 2008;27:265-8.

16. Hu SW, Cotliar J: Acute graft versus host disease following hematopoietic stem cell transplantation. Dermatol Ther 2011;24:411-23. 